\title{
Pengaruh Kualitas Layanan dan Kepuasan Terhadap Loyalitas Mahasiswa (Studi Kasus Program Pascasarjana Fakultas Ekonomi dan Bisnis Universitas Airlangga)
}

\author{
Windasari \\ Universitas Negeri Surabaya \\ windasari@unesa.ac.id \\ Soedjarwo \\ Universitas Negeri Surabaya \\ soedjarwo@unesa.ac.id \\ Toho Cholik Mutohir \\ Universitas Negeri Surabaya \\ toho.ditjora@yahoo.com
}

\begin{abstract}
Higher education institutions need to reform the organization culture of a bureucratic university become a corporate university. Education will be oriented towards high academic quality, service quality, and as well as student satisfaction. The purposes of this study are to measure and determine the effect of service quality and satisfaction on student loyalty in higher education sector. Data collection technique is done by distributing questionnaires with 5-point likert scale. There are 151 students chosen using cluster random sampling. The validity test used factor analysis. Data analysis technique was done using Structural Equation Modeling (SEM) with the help of the AMOS version 21.0 program. The result of the research shows that service quality and satisfaction simultaneously affect student loyalty.
\end{abstract}

Keywords: Service Quality, Loyalty, Satisfaction, Student

\section{Article Info}

Received date: 7 Oktober 2020

Revised date: 8 Februari 2021

Accepted date: 21 Juni 2021

\section{PENDAHULUAN}

Sektor pendidikan akhir-akhir ini telah mengalami perubahan yang sangat drastis dengan ditandai semakin ketatnya persaingan antara pengelola yang berada dalam sektor industri pendidikan untuk memperebutkan pasar yang sama. Pendidikan tinggi juga mengalami persaingan yang semakin ketat antar universitas, baik milik pemerintah maupun swasta sehingga mahasiswa seringkali membandingkan dengan universitas lainnya jika mereka merasakan ketidakpuasan kepada suatu universitas. Berdasarkan hal tersebut maka universitas harus senantiasa melakukan strategi-strategi yang dirasakan dapat menumbuhkan kepuasan kepada mahasiswa.

Loyalitas mahasiswa baru-baru ini menjadi tema strategis yang sangat penting bagi lembaga yang menawarkan pendidikan tinggi (Hennig-Thurau, Thorsten and Langer, Markus and Hansen, 2001). Loyalitas mahasiswa seharusnya berhubungan positif dengan 
kepuasan mahasiswa dan hal tersebut akan menyebabkan institusipendidikan tinggiakan menghasilkan kinerja yang baik dalam jangka waktu yang panjang.

Kompleksitas permasalahan yang sedang dihadapi perguruan tinggi di Indonesia adalah rendahnya mutu pendidikan dalam pelaksanaan pendidikan, dan hal tersebut merupakan sebuah tantangan dan tanggungjawab yang harus dicarikan solusi nyata untuk mengatasinya. Perguruan tinggi dituntut untuk merespon dengan melakukan reformasi kultural, yakni mengubah kebiasaan lama yang tidak sesuai lagi dengan dengan tuntutan zaman. Budaya lama yang melekat dalam cara kerja bureucratic university, harus diubah menjadi corporate university. Dengan demikian, Pendidikan tinggi akan selalu mengutamakan nilai-nilai yang berorientasi pada mutu akademik tinggi, produktivitas, keakurasian, dan kecepatan, juga orientasi pada kepuasan stakeholder.

Konsep untuk pengukuran loyalitas mahasiswa berdasarkan definisi dari (Oliver, 1997) "komitmen yang dipegang teguh untuk menggunakan kembali atau repatronize produk atau jasa yang disukai secara konsisten di masa depan, meskipun pengaruh situasional dan upaya pemasaran berpotensi menyebabkan perilaku beralih".

Menurut (Martensen et al., 2000), loyalitas dapat diukur melalui:

1. Niat untuk melanjutkan pendidikan, konferensi, dll, di institusi pendidikan tinggi dimasa depan

2. Niat untuk merekomendasikan institusi pendidikan tinggi

3. Niat untuk merekomendasikan program studi pendidikan tinggi

4. Memilih institusi pendidikan tinggi yang sama

5. Memilih program studi yang sama jika mahasiswa harus memilih

Berdasarkan pendapat (Athiyaman, 1997) loyalitas adalah kombinasi antara kesediaan mahasiswa untuk berbicara positif tentang institusi dan memberikan informasi kepada calon mahasiswa baru.

(Helgesen \& Nesset, 2007) mendefinisikan bahwa loyalitas mahasiswa memiliki tambahan komponen sikap yang terdiri dari tiga unsur, yaitu:

1. Kognitif (proses memperoleh pengetahuan dengan menggunakan penalaran, intuisi, atau persepsi),

2. Afektif (emosional atau sentimental),

3. Konatif (proses mental yang melibatkan kehendak) unsur-unsur dan bahwa hal itu berkaitan dengan penilaian keinginan mahasiswa.

(Helgesen \& Nesset, 2007) menyatakan bahwa loyalitas mahasiswa tidak terbatas pada waktu studi, tetapi juga setelah selesai studi, seperti yang telah disebutkan ketika mahasiswa telah menjadi alumni mahasiswacenderung untuk bertindak sebagai advokat.

(Sung \& Yang, 2009) mempublikasikan penelitian tentang hubungan mahasiswa, universitas serta reputasi. Penelitian ini menjelaskan terdapat tiga dimensi yang mendukung niat perilaku mahasiswa sebagai berikut:

1. Niat mereka untuk memberi kepada universitas sebagai alumni

2. Niat mereka untuk melanjutkan pendidikan di universitas

3. Niat mereka untuk memberikan arahan kepada orang lain tentang universitas

Dalam dunia pendidikan loyalitas dibutuhkan untuk mengembangkan dan menjalin hubungan yang solid dengan mahasiswa dimana pada akhirnya mereka yang akan membantu dan memberikan bantuan keuangan untuk universitas di masa depan. Dari beberapa ulasan tersebut terdapat beberapa indikator kunci terhadap loyalitas yaitu; a) rekomendasi atau bercerita hal positif, b) perilaku pemilihan berulang atau patronase, dan c) kontribusi kepada universitas. 
Sebagai Program Studi yang memiliki kualitas bagus dan diakui secara global, Program Pascasarjana Fakultas Ekonomi dan Bisnis masih mengalami fluktuasi jumlah mahasiswa baru yang mendaftar pada program pascasarjana. Apakah kualitas layanan yang diberikan tidak bisa memberikan kepuasan kepada mahasiswa sehingga tidak diperoleh loyalitas. Niat para alumni dan lulusan untuk memberikan kontribusi dalam kegiatan kampus masih belum cukup terlihat dengan masih kurangnya minat alumni untuk menghadiri kegiatan yang diselenggarakan oleh fakultas.

Berdasarkan uraian diatas penulis tertarik untuk meneliti tentang kualitas layanan dan kepuasan terhadap loyalitas mahasiswa. Maka dalam penelitian ini akan dibahas mengenai "Pengaruh Kualitas Layanan dan Kepuasan terhadap Loyalitas Mahasiswa Pascasarjana Fakultas Ekonomi dan Bisnis Universitas Airlangga.

\section{METODE PENELITIAN}

Penelitian ini merupakan penelitian kuantitatif dengan menggunakan teknik Structural Equation Modelling (SEM) untuk menguji apakah model penelitian ini fit atau tidak. Teknik pengumpulan data dengan metode survey menggunakan kuesioner yang terdapat 26 item pertanyaan yang merupakan penjabaran setiap variabel. Metode penarikan sampel yang digunakan adalah cluster random sampling sehingga jumlah sample yang diambil dari populasi yang ada sebanyak 151 mahasiswa.

Dalam penelitian ini akan digunakan uji validitas dengan Confirmatory Factor Analysis dengan bantuan software SPSS for windows versi 21. Analisis data menggunakan Structural Equation Modelling. Adapun langkah-langkah dalam Structural Equation Modelling adalah sebagai berikut Bollen and Long, (Latan, 2013).

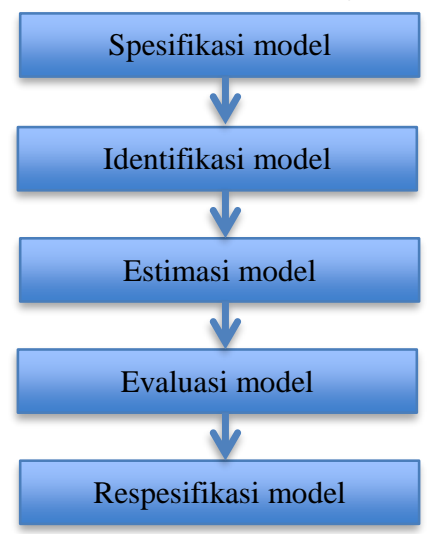

\section{Gambar 1. Tahapan analisis menggunakan} SEM

Merumuskan konseptualisasi model ke dalam path diagram. Diagram jalur digambarkan sesuai konsep dengan menggunakan amos.

Adapun spesifikasi model pada penelitian ini digambarkan pada gambar 2 dibwah ini.

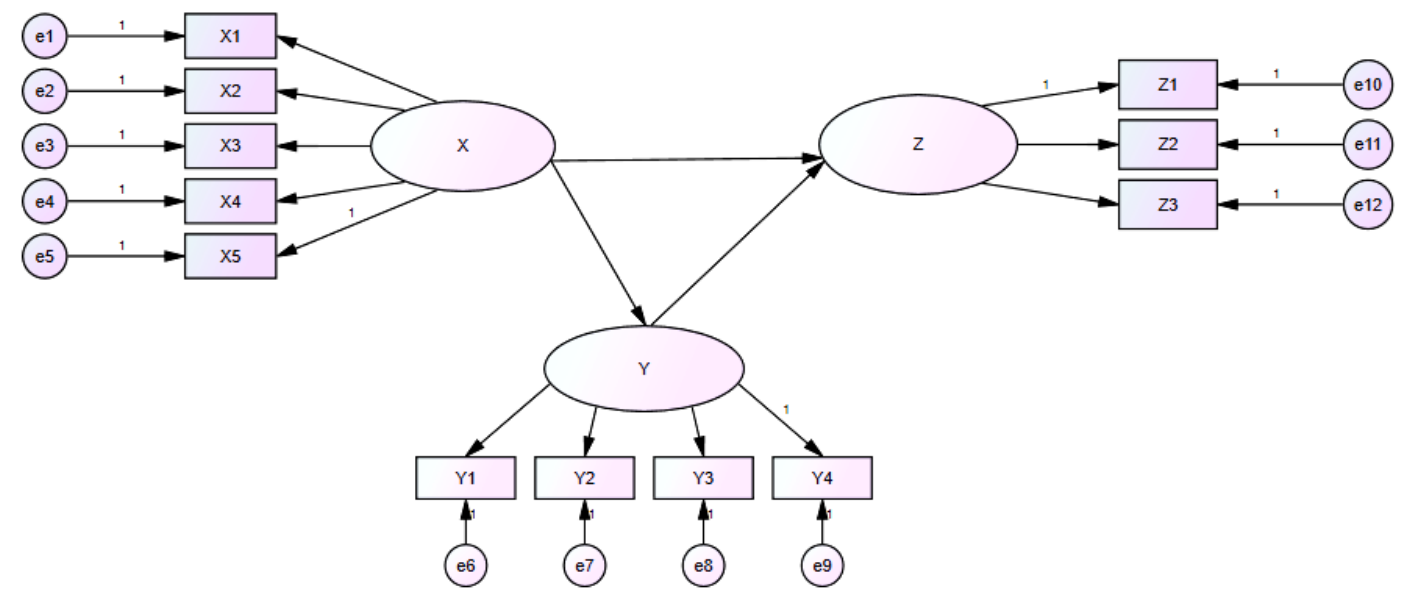

Gambar 2. Spesifikasi Model 


\section{Dimana:}

1. Kualitas layanan diukur dengan 5 dimensi dengan menggunakan skala likert

(Parasuraman et al., 1996).

$\mathrm{X} 1$ = Tangible

$\mathrm{X} 2$ = Reliability

$\mathrm{X} 3$ = Responsiveness

$\mathrm{X} 4$ = Assurance

$\mathrm{X} 5$ = Emphaty

2. Kepuasan mahasiswa diukur dengan 4 dimensi dengan menggunakan skala likert.

Munawar, et.al., (Coskun, 2014)

$\mathrm{Y} 1$ = Fasilitas kampus

Y2 = Pengajaran

$\mathrm{Y} 3=$ Teknologi

Y4 = Relasi

3. Loyalitas mahasiswa diukur dengan 3

dimensi dengan menggunakan skala likert.

(Oliver, 1997)

$\mathrm{Z} 1$ = Rekomendasi

$\mathrm{Z} 2$ = Pemilihan ulang

$\mathrm{Z} 3$ = Kontribusi

\section{HASIL PENELITIAN DAN \\ PEMBAHASAN}

\section{Hasil Penelitian}

Didalam penelitian ini mengukur pengaruh kedua variabel kualitas layanan dan kepuasan secara simultan terhadap loyalitas mahasiswa. Menurut (Hair et al., 2010) factor loading lebih besar dari 0.30 dianggap memenuhi level minimal, factor loading lebih besar 0.40 dianggap lebih baik dan sesuai dengan rules of thumb yang dipakai para peneliti, dan factor loading lebih besar dari 0.50 dianggap signifikan. Berdasarakan uji validitas yang dilakukan dapat diperoleh hasil pada tabel 1 dibawah ini.

Tabel 1. Hasil Uji Validitas

\begin{tabular}{|c|c|c|c|c|}
\hline Variabel & Kuali & Kepua & Loyali & Keteran \\
\hline Tangible & 0,510 & & & Valid \\
\hline Reliability & 0,534 & & & Valid \\
\hline Responsive & 0,513 & & & Valid \\
\hline Assurance & 0,682 & & & Valid \\
\hline Emphaty & 0,591 & & & Valid \\
\hline Fasilitas & & 0,513 & & Valid \\
\hline
\end{tabular}

\begin{tabular}{|c|c|c|c|c|}
\hline Variabel & Kuali & Kepua & Loyali & Keteran \\
\hline Pengajaran & & 0,707 & & Valid \\
\hline Teknologi & & 0,525 & & Valid \\
\hline Relasi & & 0,659 & & Valid \\
\hline Staff & & 0,691 & & Valid \\
\hline Memilih & & & 0,682 & Valid \\
\hline Rekomend & & & 0,723 & Valid \\
\hline Donasi & & & 0,703 & Valid \\
\hline
\end{tabular}

Hasil uji validitas menunjukkan bahwa ketiga variabel yaitu variabel kualitas layanan, kepuasan dan loyalitas hasilnya valid karena nilai factor loading dari ketiga variabel tersebut memnuhi standar minimal. Tabel diatas menunjukkan nilai factor ketiga variabel diatas 0,5 sehingga variabel tersebut dinyatakan valid dan signifikan. Adapun uji reliabilitas yang dilakukan menghasilkan data sesuai dengan tabel 2 dibawah ini.

Tabel 2. Hasil Uji Reliabilitas

\begin{tabular}{cccc}
\hline Variabel & Standar & Hasil & Keteranga \\
\hline Tangible & 0,60 & 0.695 & Reliabel \\
\hline Reliability & 0,60 & 0.705 & Reliabel \\
\hline Responsivene & 0,60 & 0.712 & Reliabel \\
\hline Assurance & 0,60 & 0.697 & Reliabel \\
\hline Emphaty & 0,60 & 0.704 & Reliabel \\
\hline Fasilitas & 0,60 & 0.698 & Reliabel \\
\hline Pengajaran & 0,60 & 0.689 & Reliabel \\
\hline Teknologi & 0,60 & 0.711 & Reliabel \\
\hline Relasi & 0,60 & 0.698 & Reliabel \\
\hline Staff & 0,60 & 0.700 & Reliabel \\
\hline Memilih & 0,60 & 0.758 & Reliabel \\
\hline Rekomendasi & 0,60 & 0.745 & Reliabel \\
\hline Donasi & 0,60 & 0.735 & Reliabel
\end{tabular}

Berdasarkan data pada tabel diatas dapat dilihat bahwa hasil dari semua variabel memiliki koefisien Cronbach's Alpha $>0,60$, maka seluruh instrumen untuk mengungkap lima variabel kualitas layanan, tlima variabel kepuasan dan tiga variabel loyalitas adalah reliabel (konsisten/handal). Evaluasi nilai goodness-of-fit dari model penelitian yang diajukan dapat dilihat pada Tabel 3.

Tabel 3. Hasil Uji Goodness-of -Fit

\begin{tabular}{lccc}
\hline \multicolumn{1}{c}{ Goodnes } & Cutt of & Hasil & Evaluasi \\
\hline Chi & Diharanka & 60.97 & Fit \\
\hline Probabilit & $>0.05$ & 0.370 & Fit \\
\hline CMIN/DF & $>2.0$ & 1.051 & Fit \\
\hline GFI & $>0.90$ & 0.941 & Fit \\
\hline AGEI & $>0.90$ & 0.907 & Margina \\
\hline TLI & $>0.95$ & 0.987 & Fit \\
\hline CFI & $>0.95$ & 0.990 & Fit \\
\hline RMSEA & $<0.08$ & 0.018 & Fit \\
\hline
\end{tabular}


Goodness of Fit Index (GFI) mencerminkan tingkat kesesuaian model secara keseluruhan yang dihitung dari residual kuadrat dari model yang diprediksi dibandingkan data yang sebenarnya. Nilai yang mendekati 1 mengisyaratkan model yang diuji memiliki kesesuaian yang baik. Dengan tingkat penerimaan yang direkomendasikan sebesar $\geq 0,90$, dapat disimpulkan bahwa model memiliki tingkat kesesuaian yang marginal dengan nilai GFI sebesar 0,941

Seperti yang telah dijelaskan sebelumnya, dalam mengukur variabel kualitas pelayanan, pengukuran dilakukan berdasarkan lima dimensi konstruk yaitu: bukti fisik, keandalan, daya tanggap, jaminan, dan empati. Dari pengukuruan lima konstruk tersebut terhadap kepuasan mahasiswa, diperoleh hasil analisis data secara statistik menunjukkan bahwa kualitas pelayanan berpengaruh langsung positif dan signifikan terhadap kepuasan mahasiswa Pascasarjana Fakultas Ekonomi dan Bisnis Universitas Airlangga.

Tabel 4. Evaluasi bobot regresi uji kausalitas

\begin{tabular}{lll|rrrr}
\hline & & Variabe & \multicolumn{1}{c}{ Estima } & \multicolumn{1}{c}{ S. } & C. & P \\
\hline kepuasa & $<--$ & Kualita & 1.034 & .251 & 4.117 & $* * *$ \\
\hline loyalita & $<--$ & Kualita & 1.546 & .566 & 2.733 & .00 \\
\hline loyalita & $<--$ & Kepuas & .315 & .220 & 1.435 & .04 \\
\hline
\end{tabular}

Tabel 4 di atas menunjukkkan kualitas pelayanan memiliki nilai C.R sebesar 4,117 dengan nilai probabilitas sebesar 0,000 , yang berarti kualitas pelayanan berpengaruh signifikan positif (meningkatkan) kepuasan mahasiswa. Hubungan kualitas pelayanan dengan loyalitas menunjukkan nilai C.R sebesar 2,733 dengan nilai probabilitas sebesar 0,006 yang berarti kualitas pelayanan berpengaruh signifikan meningkatkan loyalitas mahasiswa. Kepuasan mahasiswa memiliki nilai C.R sebesar 1,435dengan nilai probabilitas sebesar 0,041 berarti kepuasan berpengaruh terhadap loyalitas.

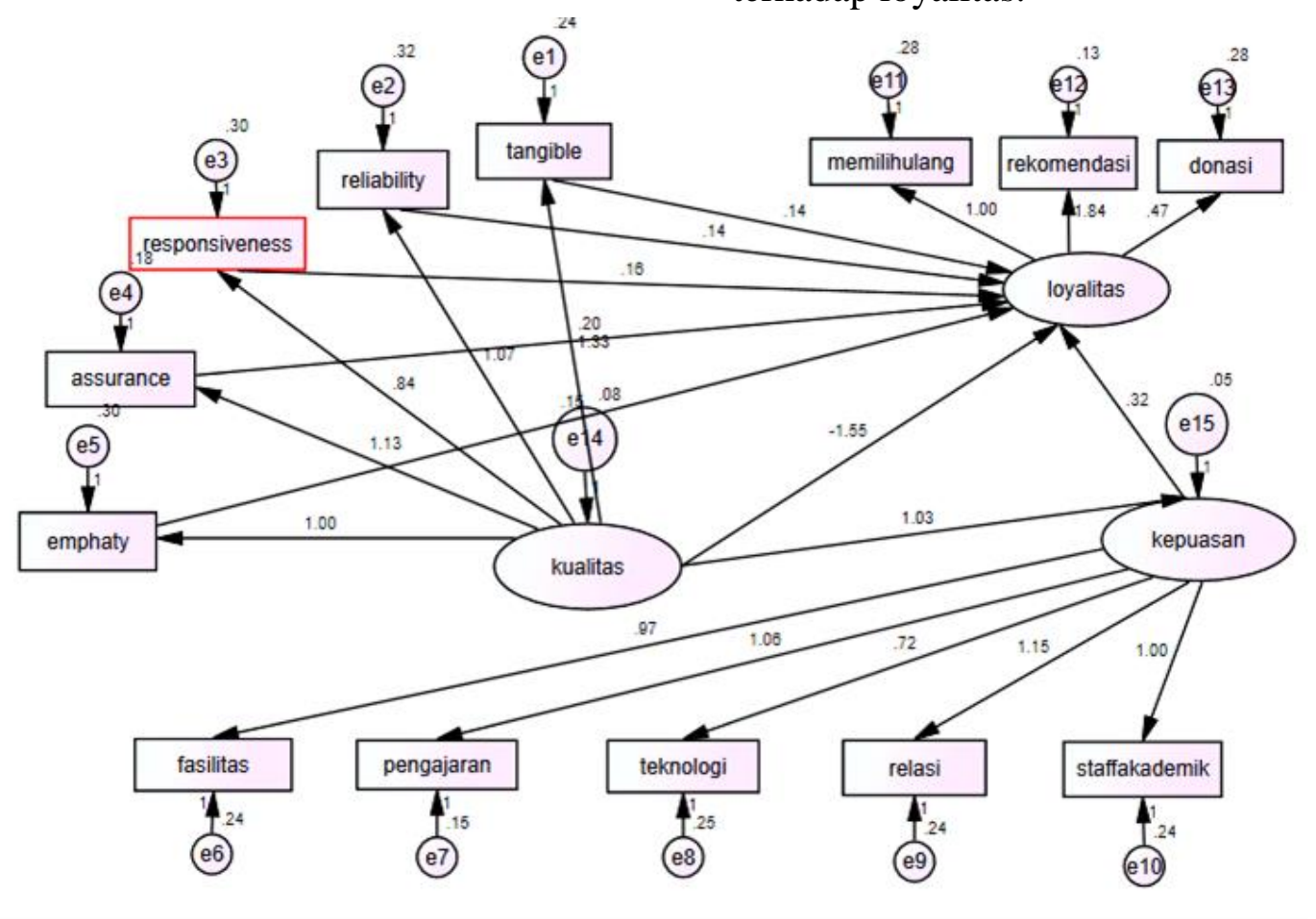

Hasil analisis data statistik menunjukkan bahwa kualitas pelayanan dan kepuasan berpengaruh positif dan signifikan terhadap loyalitas mahasiswa di Pascasarjana Fakultas Ekonomi dan Bisnis Universitas Airlangga (FEB Unair). Semakin baik kualitas pelayanan yang diberikan oleh program pascasarjana FEB Unair maka semakin tinggi pula loyalitas mahasiswa yang diperoleh. (Fares et al., 2017) menyatakan bahwa kualitas pelayanan yang baik akan menghasilkan kepuasan pelanggan yang tinggi yang dapat 
meningkatkan loyalitas pelanggan. (HennigThurau, Thorsten and Langer, Markus and Hansen, 2001) terdapat hubungan yang positif dan signifikan antara kualitas pelayanan terhadap loyalitas pelanggan. Selain itu, penelitian ini juga membuktikan bahwa kepuasan berpengaruh positif dan signifikan terhadap loyalitas mahasiswa program pascasarjana FEB Unair.

Pendidikan tinggi berkomitmen untuk memberikan layanan berkualitas dan memberikan kepuasan yang mengesankan, sehingga mahasiswa dapat menjadi duta dalam mempromosikan universitas kepada temanteman dan anggota keluarga (Le Roux \& Van Rensburg, 2014). Gambar diatas tersebut juga menjelaskan bahwa kualitas layanan dan kepuasan memiliki suatu hubungan langsung yang dapat mempengaruhi loyalitas mahasiswa. Hal tersebut berarti kualitas layanan dan kepuasan merupakan kedua komponen penting dalam mengembangkan loyalitas mahasiswa pascasarjana FEB Unair.

(Chen et al., 2014) menunjukkan bahwa selama masa kuliah, kepuasan mahasiswa terhadap sekolah mereka berpengaruh positif terhadap kesediaan mereka untuk merekomendasikan pendidikan mereka setelah lulus, ataupun untuk melanjutkan pendidikan di tempat yang sama. Oleh karena itu, kepuasan mahasiswa dari aspek fasilitas, teknologi, relasi dan juga staff akademik harus diberikan secara maksimal untuk memperoleh kepuasan mahasiswa. Mudahnya penggunaan akses fasilitas pembelajaran dan pendukung pembelajaran dapat meningkatkan kepuasan mahasiswa selain itu ketersediaan teknologi seperti akses jurnal dan wifi juga berkontribusi dalam memberikan kepuasan kepada mahasiswa.

Pada hasil analisis penelitian yang terakhir terkait dengan kualitas layanan dan kepuasan diperoleh hasil bahwa pengaruh tidak langsung lebih kuat pengaruhnya jika dibandingkan pengaruh langsung, artinya mahasiswa yang loyal terhadap FEB Unair lebih dominan ditentukan melalui kepuasan dibandingkan oleh kualitas pelayanan yang diberikan. Besaran pengaruh tidak langsung kualitas pelayanan terhadap loyalitas melalui kepuasan mahasiswa adalah sebesar 1,334. Ini berarti bahwa, kepuasan dapat menjadi variabel intervening antara kualitas pelayanan dan loyalitas. Hal tersebut menunjukkan bahwa tingkat kepuasan sangat perlu diperhatikan dalam upaya memperoleh loyalitas mahasiswa pada mahasiswa pascasarjana FEB Unair.

Kepuasan juga berkorelasi positif dengan keunggulan kompetitif perguruan tinggi (Dharmayanti et al., 2018). Kemampuan bersaing perguruan tinggi akan semakin meningkat karena adanya kepuasan yang dirasakan oleh mahasiswa. Kepuasan yang dirasakan tersebut mengindikasikan adanya peningkatan kinerja dari perguruan tinggi sehingga dapat meningkatkan keunggulan bersaingnya. Dengan maksimalnya kualitas layanan yang diberikan di FEB Unair dan tingginya tingkat kepuasan mahasiswa maka ini berkontribusi untuk meningkatkan loyalitas dan keunggulan bersaingnya.

\section{SIMPULAN DAN SARAN \\ Simpulan}

Kualitas layanan dan kepuasan mahasiswa secara bersama-sama berpengaruh positif dan siginifikan sebesar terhadap loyalitas mahasiswa pascasarjana FEB Unair. Kepuasan memegang peranan yang signifikan terhadap loyalitas mahasiswa dan keunggulan bersaing FEB Unair.

Adapun saran untuk peneliti kedepannya adalah bahwa ruang lingkup studi ini difokuskan pada mahasiswa program pascasarjana FEB Unair yang berdampak pada generalisasi studi yang terbatas. Keterbatasan ini mengisyaratkan perlunya studi studi lanjutan untuk menggeneralisasi hasil-hasil yang diperoleh pada konteks yang berbeda dan 
lebih luas, salah satunya adalah kontribusi brand image fakultas terhadap loyalitas.

\section{DAFTAR PUSTAKA}

Athiyaman, A. (1997). Linking student satisfaction and service quality perceptions: The case of university education. European Journal of Marketing, 31(8), 528-540.

Chen, Chen, C.-F. and, \& Chin-Tsu. (2014). The Effect of Higher Education Brand Images on Satisfaction and Lifetime Value from Students' Viewpoint. Anthropologist, 17(01), 137-145.

Dharmayanti, D., Semuel, H., \& Devie. (2018). The Students Satisfaction, Student Loyalty, Competitive Advantage And Financial Sustainability On Private Universities In Surabaya. Advances in Social Sciences Reearch Journal, 5(10), 266-275.

Fares, D., Achour, M., \& Kachkar, O. (2017). The impact of service quality, student satisfaction, and university reputation on student loyalty: A case study on international students in iium, malaysia. Information Management Business Review, 5(12), 584-590.

Hair, J. F., Black, W. C., Babin, B. J., \& Anderson, R. E. (2010). Multivariate Data Analysis. Prentice Hall.

Helgesen, Ø., \& Nesset, E. (2007). Images, Satisfaction and Antecedents: Drivers of Student Loyalty? A Case Study of a Norwegian University College. Corporate Reputation Review, 10(1), $38-59$. https://doi.org/10.1057/palgrave.crr.15 50037
Hennig-Thurau, Thorsten and Langer, Markus and Hansen, U. (2001). Modeling and Managing Student Loyalty: An Approach Based on the Concept of Relationship Quality. Journal of Service Research - J SERV RES, 3(5), 331-344. https://doi.org/10.1177/1094670501340 06

Le Roux, A., \& Van Rensburg, R. J. (2014). Student perceptions of customer experience in a higher education environment. Acta Commercii, 14(1), $1-9$.

https://doi.org/10.4102/ac.v14i1.232

Martensen, A., Grønholdt, L., Eskildsen, J., \& Kristensen, K. (2000). Measuring student oriented quality in higher education: Application of the ECSI methodology. Sinergie - Rapporti Di Ricerca, 9(1), 371-383.

Oliver, R. L. (1997). Satisfaction: A Behavioral Perspective on the Consumer. McGrawHill.

Parasuraman, Leonard, \& Valarie. (1996). The behavioral consequences of service quality. Journal of Marketing, 60(2), 31-46.

Sung, M., \& Yang, S. U. (2009). Studentuniversity relationships and reputation: A study of the links between key factors fostering students' supportive behavioral intentions towards their university. Higher Education, 57(6), 787-811. https://doi.org/10.1007/s10734-0089176-7 